\title{
Empathy Education Based Classroom Through Emotional Engagement during the Pandemic
}

\author{
Alimul Muniroh \\ IAI TABAH Lamongan \\ alimulmuniroh@iai-tabah.ac.id
}

Article History $\quad$ Received : Feb 9th 2021

Revision : April 13 $13^{\text {th }} 2021$

Publication : June 30th 2021

\begin{abstract}
:
This article aims to explain how empathy education can be taught to students through emotional engagement. Empathy is a mental condition of a person who is connected to others because there is a sense of belonging while emotional engagement is a mental activity where there is individual self-involvement with the activities they do. In this pandemic, empathy and emotional engagement are needed by students, because with this mental attitude, a student can feel awareness and involvement with other students so that if someone in his environment is affected by a disaster, then the student is immediately moved to help the affected person. The conclusion of the article shows that empathy character is needed by students as a result of learning. Therefore, teachers need to design learning that encourages students to have a sense of empathy and emotional engagement that is very useful, especially in this pandemic era.
\end{abstract}

Keywords: Empathy, engagement, pandemic

\section{INTRODUCTION}

The Covid-19 pandemic has led to fundamental changes in every aspect of daily life. There are new health guidelines and protocols. There are also new habits in society. Pandemics not only attack certain groups of people but also all walks of life. Now the important thing that people need is empathy for this pandemic.

Empathy is a condition of a person that makes one feel himself or herself in the same state, feeling or mind as the other person. This feeling in Islam is mentioned in riwatat Bukhori, "kal bunyanin yasuddu ba'dhuhu ba'dhon" (Like one building to another solidifying each other). Empathy makes people feel the pain or sadness experienced by others, so that with this sense society can become resilient in the face of this pandemic.

Empathy is required by every community including students who are studying at their school. Schools are among the neighborhoods vulnerable to the covid 19 virus. In school students interact with their peers, in the classroom they do tasks together so it is not surprising that the school is an institution that needs to be protected from the spread of this virus. 
The spread of Covid-19 needs to be prevented, but prevention cannot be done alone. This prevention requires the involvement of all students. With the involvement of all students, prevention of the spread of Covid-19 can be minimized. Therefore today students need to be educated how they empathize and have involvement in their lives. This paper explains how empathy education can be taught to students through emotional engagement, so that with increasing emotional engagement can also increase empathy of students in others.

\section{Empathy Education for Students}

Inliterature, the concept of empathy is still ambiguously defined (Cooper, 2011). The word empathy evolved from German literature, Einfühlung. The word is defined as the power of one's mental identification of another person or the object he or she thinks of (Brown, 1993). In other literature it is mentioned that empathy is a feeling that is more at the with (with) one than just for (for) that person. These feelings indicate that others are subjects to us not an object for us (Rogers, 1975, Noddings, 1986). From these literature it can be said that empathy is the feeling of a person who has a deep connection with others, so that it seems to be able to feel what the other person is experiencing.

Because empathy is a psychological feeling, empathy is often associated with one's emotions. Empathy can occur in everyone in their own activities, such as in work, social relationships, research and including education. Watts (2008) exemplifies empathy associated with the work of developing emotions and fostering rapport on informants in qualitative research activities. In turn, such empathy can lead to trust and attention from participants in researchers.

Empati can be developed in human beings through training and education (Rogers, 1975),. In 1972 in England a special training was held to ensure the teacher's attention to his pupils called empathy training (Hargreaves, 1972), after which empathy training also developed in other countries.

Growing empathy in education in students is very important. Empathy makes students not only meet, socialize and interact but they can also feel each other's feelings so as to raise concern for each other. The feeling of empathy that arises can also increase the sense of belonging of students at the school's alma mater even when they have retired from school. Training sensitivity to have empathy is necessary since childhood. The earlier empathy is possessed, the more likely empathy is to grow in students. Therefore, in school, the growth of empathy can be done since the child enters the school. The growth of empathy since childhood can help the child's mental development.

According to Cooper (2011) empathy has several levels. Fundamentally, in a classroom, empathy can be identified from characteristics and communication. These two things are part of the social interaction that occurs in daily learning, and both of them can be further divided into several parts. A6 important characters in 
empathy that can be known during the learning process, namely accepting and being open, giving attention, hearing, interest, taking a positive side and affirmative approach, and anantusias. These six traits are characters that often appear in the learning that students and teachers show when they show their empathy to others in the classroom.

In addition, according to Cooper (2011), empathy must be supported by a good way of communication. A teacher if you want to give empathy learning must master how to communicate well, including being able to show facial expressions and interactions to students, showing body language gestures and movements that can touch students' attention, maintain height and distance, and use the right language and tone of speech. Both characteristics and ways of communicating are inseparable in empathy learning in the classroom.

Furthermore, to be able to know how empathy arises in learning, we can look at that empathy in three categories, namely on personal interaction, focused group interaction, and unfocused group interaction. In personal interactions, empathy is seen from the association between students and students in person. Usually every student has a soulmate or a pair of close friends who are always together. In these personal interactions teachers can record students' behavior individually.

Instead of focus group interactions and unfocused group interactions, teachers can look at students' empathy in the classroom or in school. For focused group interactions can be aimed at groups of students over 2 who form a study group or playmates together. While group interactions are not focused, empathy can be observed in students associated with association with other friends at school.

\section{Emotional Engagement and Empathy Education in the Pandemic}

Engagement can be interpreted as the energy in doing something that indicates the existence of a relationship of self-involvement between an individual and his activity (Appleton et al., 2006). Engagement is also the participation of students both in academic activities and from non-academic activities (Audas \&Willms, 2001). The word engagement develops in educational psychology because it relates to psychological development (Reddy, Rhodes, \&Mulhall, 2003) and student academic graduation (Appleton et al., 2006; Fredricks, Blumenfeld, \& Paris, 2004).

Chapman (2003) describes engagement as a willingness to participate in routine school activities, such as attending classes, giving up the necessary work, and following the direction ofa teacher in the classroom. Engagement has a fairly complex structure including cognitive engagement, behavioral engagement, and emotional engagement. (Fredricks, Blumenfeld, \& Paris, 2004; Chapman, 2003).

Conceptually, the position of the three domains is balanced. However, Sagayadevan and Jeyaraj (2012) stated that emotional engagement is less revealed than the other two domains. Although there are interesting studies that show that students who are emotionally involved with their school, then the student can show 
high academic achievement (Stipek, 2002). From these reviews it can be known that emotional engagement improves the empathy character of the child. Emotional engagement is a form of ownership of the school and acceptance of the school's goals and values. Examples of emotional engagement are reactions in the classroom, feelings directed at the teacher, identifying with the school, feeling possessed and possessed, appreciating success in the classroom.

Empathy education is very important especially when we enter the era of the Covid-19 pandemic where people experience tragic conditions in their lives. Limited living space due to Covid-19 makes people in a depressed condition and need help each other in their lives. No single layer of society is free from the dangers of Covid19.

The existence of empathy education can make the child become moved by life in their environment. Empathy gives awareness that their environment is concerned so that they actively take a role in preventing the transmission of this virus. Furthermore,the development of empathy is useful to cure people's fears of problems that occur in society, even problems that can cause social divisions (Cooper, 2011).

\section{Empathy Education through Emotional Engagement}

The study revealed above shows that the essence of emotional engagement is to foster empathy for students. In this effort Students must be invited to feel others in their lives. Students feel the teacher's presence in learning so that they have respect for the teacher and they can establish a positive relationship. Pandemics should not deter students from interacting with their teachers. The learning medium prepared by the teacher should be able to make students feel that they are connected to the teacher in a good learning.

Education in the pandemic must keep students in touch with their friends. Teachers design learning tasks that are done in groups so that students can still work with their friends in doing tasks. Teachers do not design learning tasks that are only individual but these activities can make students also interact with their environment so that students can feel correctly the presence of pandemics is a shared problem that must be prevented together.

Empathy education and emotional engagement emphasize psychological aspects. This shows that both empathy and emotional engagement seek to develop relationships between teachers and students, as well as students with other students. Strengthening human relationships in the learning process can make each individual have empathy in the other individual. In the case of pandemic, if the student uses a mask during learning then he has the awareness that the use of the mask is not only for his own benefit, but also to keep his friend in order to minimize the spread of Covid-19. 
The emphasis on the psychological aspect of empathy was also conveyed by Brown, 1993, Rogers, (1975), Noddings, (1986), who explained that empathy is a feeling associated with others. While psychological in academic engagement is emphasized by Appleton, et al (2006), Ryan \&Deci (2000). Emotional engagement can be obtained from the interaction of Patrick, Ryan, \&Kaplan (2007), and if the interaction is heading in a positive direction then it can support the learning process skinner, et al (2008).

In the relationship that has been built, teachers can explain that they really have to take care of each other in their daily lives. Teachers can state that in health is a shared affair in the classroom. Each student should respect and take care of each other's health. Teachers can also give examples of the use of such masks when doing learning privileges. Thus students can feel that they are one unit, which if one of the students or teachers has a disaster then the other is sorry for the disaster.

The student's empathy can also be seen from the character of the student and the way the teacher delivers in learning. Important characters in empathy include receiving and being open, paying attention, hearing, being interested, taking a positive side and affirmative approach, and being enthusiastic. The picture of accepting and openness in learning is that teachers accept students' understanding and respond positively to students' thoughts to develop their capacity.

Teachers openly encourage students to share ideas and invite them to have a dialogue about them. Caring attitudes are very important for teachers and students, because they can increase students' involvement in classroom learning. With attention, problems that arise during learning can also be reduced.

Empathetic teachers are teachers who want to hear students. Teachers hear students' opinions individually, taking the time to listen to students in order to understand their deepest desires. By hearing, teachers can clarify students' opinions. A sense of interest can be shown by the teacher in any student's views, questions, or answers. interest is also initiated by students in other students and in the information submitted by the teacher. The emergence of this sense can make interactions in the classroom become more vibrant.

In Empathy Education can also be done by taking a positive side and affirmative approach. Every student's opinion or action must have good or bad consequences, by choosing the positive side of what happens the teacher and the student can take wisdom from every incident in the classroom. The affirmative approach will educate students to be careful in their attitude in class, because every action done will definitely have consequences on other students. While the enthusiastic attitude towards proactive attitude towards learning in the classroom. Positive relationships between teachers and students can increase enthusiasm in learning. Teachers have a high spirit in giving lessons while students have the spirit to follow the learning.

The overall character of empathy in the learning can occur if there is positive support from the teacher to the student as well as from the student to the other 
student. The character must also be supported by a good way of communicating in the classroom, so that empathy can arise through learning in the classroom.

\section{CONCLUSION}

Based on the discussion that has been described can be shown that emotional engagement and empathy education in the classroom have a connection because both themes emphasize the psychological aspects of learning. Empathy can be taught through learning in the classroom. In the learning, teacher-student interaction and teacher support in students are important keys in learning to develop child empathy in the classroom. Empathy learning must be able to realize the character of students including accepting and being open, giving attention, hearing, interest, taking a positive side and affirmative approach, and being enthusiastic.

In this pandemic, empathy character is needed as a real form of learning. Teachers should be able to create learning that encourages students to have involvement in preventing the spread of covid-19. The togetherness between teachers and students, as well as students with other students in greatly helping the community to break the chain of viruses that in turn can encourage us all to immediately be free from pandemics.

\section{REFERENCE}

Appleton, J.J., Christenson, S.L., Kim, D. \& Reschly, A.L. (2006). Measuring Cognitive and Psychological Engagement: Validation of The Student Engagement Instrument. Journal of School Psychology, 44: 427-445.

Audas, R. \& Willms, J. D. (2001). Engagement and Dropping Out of School: A Life Course Perspective. Human Resources and Social Development Canada. diakses 16 Desember 2012.

Brown, L. (1993 ) The New Shorter Oxford English Dictionary. New York: Oxford University Press.

Cooper, B. (2011). Empathy in Education: Engagement, Values and Achievement. Newyork: Continuum.

Chapman, E. (2003). Alternative Approaches to Assessing Student Engagement Rates. Practical Assessment, Research \& Evaluation, (Online), 8(13): (http://PAREonline.net/getvn.asp?v=8\& n=13.), diakses 18 November 2011.

Finn, J.D. (1989). Withdrawing from School. Review of Educational Research, 59 (2): 117-142.

Frederick, J. A., Blumenfeld, P. C. \& Paris, A. H. (2004). School Engagement: Potential of the Concept State of The Evidance. Review of Educational Research. 74: 59109.

Hargreaves, D. H. (1972). Interpersonal Relations and Education. London: Routledge and Kegan Paul. 
Hughes, J.N., and Kwok, O.M. (2007). Influence of Student-Teacher and ParentTeacher Relationships on Lower Achieving Readers' Engagement and Achievement in the Primary Grades. Journal of Educational Psychology. 99 (1): 39-51.

Noddings, N. (1986). Caring - A Feminine Approach to Ethics and Moral Education California, USA: University of California Press.

Patrick, H., Ryan, A.M., and Kaplan, A. (2007). Early Adolescents' Perceptions of the Classroom Social Environment, Motivational Beliefs, and Engagement. Journal of Educational Psychology. 99 (1): 83-98.

Reddy, R., Rhodes, J.E., and Mulhall, P. (2003). The Influence of Teacher Support on Student Adjustment in the Middle School Years: A Latent Growth Curve Study. Development and Psychopathology. 15: 119-138.

Rogers, C. R. (1975). 'Empathic: an Unappreciated Way of Being'. The Counselling Psychologist. 5, (2), 2.

Ryan, R.M., and Deci, E.L. (2000). Self-Determination Theory and the Facilitation of Intrinsic Motivation, Social Development, and Well-Being. American Psychologis., 55 (1): 68-78.

Sagayadevan, V., dan Jeyaraj, S. (2012). The Role of Emotional Engagement in Lecturer-Student Interaction and the Impact On Academic Outcomes of Student Achievement and Learning. Journal of the Scholarship of Teaching and Learning. 12 (3): 1 - 30.

Sinclair, M.F., Christenson, S.L., Lehr, C.A., and Anderson, A.R. (2003). Facilitating Student Engagement: Lessons Learned From Check \& Connect Longitudinal Studies. The California School Psychologist, 8, 29-41.

Skinner, E., Furrer, C., Marchand, G., dan Kindermann, T. (2008). Engagement and Disaffection in the Classroom: Part of a Larger Motivational Dynamic?. Journal of Educational Psychology. 100 (4): 765-781.

Stipek. (2002). Effects School Restructuring on Size and Early Gains in Achievement an Engagement. Sociology and Education. 68: 241-270.

Watts, J.H. (2008). Emotion, Empathy and Exit: Reflections on Doing Ethnographic Qualitative Research on Sensitive Topics. Medical Sociology. 3 (2): 3-14. 